\title{
Erratum: A novel humanized mouse lacking murine p450 oxidoreductase for studying human drug metabolism
}

\author{
Mercedes Barzi ${ }^{1}$, Francis P. Pankowicz¹,2, Barry Zorman³ ${ }^{3}$ Xing Liu4 ${ }^{4}$, Xavier Legras', Diane Yang ${ }^{1,2}$, \\ Malgorzata Borowiak ${ }^{1,2,5,6,7,8}$, Beatrice Bissig-Choisat ${ }^{1,5}$, Pavel Sumazin ${ }^{3,7}$, Feng Li ${ }^{4,5}$ \& Karl-Dimiter Bissig ${ }^{1,2,5,6,7}$
}

Nature Communications 8:39 doi:10.1038/s41467-017-00049-x; Article pubilshed online: 28 June 2017

An incorrect version of the Supplementary Information was inadvertently published with this article where the wrong file was included. The HTML has been updated to include the correct version of the Supplementary Information.

Published online: 17 October 2017

\begin{abstract}
(c) (i) Open Access This article is licensed under a Creative Commons Attribution 4.0 International License, which permits use, sharing, adaptation, distribution and reproduction in any medium or format, as long as you give appropriate credit to the original author(s) and the source, provide a link to the Creative Commons license, and indicate if changes were made. The images or other third party material in this article are included in the article's Creative Commons license, unless indicated otherwise in a credit line to the material. If material is not included in the article's Creative Commons license and your intended use is not permitted by statutory regulation or exceeds the permitted use, you will need to obtain permission directly from the copyright holder. To view a copy of this license, visit http://creativecommons.org/licenses/by/4.0/.
\end{abstract}

(C) The Author(s) 2017

\footnotetext{
${ }^{1}$ Center for Cell and Gene Therapy, Stem Cells and Regenerative Medicine Center, Baylor College of Medicine, Houston, TX 77030, USA. ${ }^{2}$ Graduate Program, Department of Molecular and Cellular Biology, Baylor College of Medicine, Houston, TX 77030, USA. ${ }^{3}$ Texas Children's Cancer Center, Department of Pediatrics, Baylor College of Medicine, Houston, TX 77030, USA. ${ }^{4}$ Alkek Center for Molecular Discovery, Advanced Technology Core, Baylor College of Medicine, Houston, TX 77030, USA. ${ }^{5}$ Department of Molecular and Cellular Biology, Baylor College of Medicine, Houston, TX 77030, USA. ${ }^{6}$ Program in Developmental Biology, Baylor College of Medicine, Houston, TX 77030, USA. 7 Dan L. Duncan Cancer Center, Baylor College of Medicine, Houston, TX 77030, USA. ${ }^{8}$ McNair Medical Institute, Houston, TX 77030, USA. Correspondence and requests for materials should be addressed to K.-D.B. (email: bissig@bcm.edu)
} 